\title{
Parameterization and cartographic presentation of water deficits of cultivated plants
}

\author{
Janusz Ostrowski, Leszek Labędzki*, and Ewa Kanecka-Geszke \\ Institute of Technology and Life Sciences, Hrabska 3, Falenty, 05-090 Raszyn, Poland \\ Received November 13, 2014; accepted May 12, 2015
}

\begin{abstract}
A b s t r a c t. The aim of the paper was to characterise and present cartographically water deficits of crop plants grown on different soils in Poland. The calculation of water deficits was carried out for 40 meteorological stations of the Institute of Meteorology and Water Management and the Institute of Technology and Life Sciences using meteorological data from the growing seasons 19702004 for most crops grown in Poland. Estimations were made for soils suitable for growing the selected crop plants. Water deficits were determined for a probability of exceedance of 20 and $50 \%$. They served to create a relative database. Maps of water deficit were generated for each crop and for two probabilities. The estimated share of soil area suitable for growing the particular crops was calculated for water deficits greater than $40 \mathrm{~mm}$. Water deficits of a given crop on soils suitable for growing at probabilities of their occurrence once in 5 years are also presented in the paper.

$\mathrm{K}$ e y w or d s: water deficits, crop plants, mapping, modelling
\end{abstract}

\section{INTRODUCTION}

Recorded and forecast climate changes in Poland are confirmed by current weather phenomena like long rainfree periods resulting in deficits of water necessary for the growth of crop plants. The size and frequency of these deficits is a basis for searching water reserves that determine the supply of irrigation systems and enable intensive farming. The occurrence of water deficits often has a regional range.

There are many papers devoted to water deficits of crop plants in both spatial and temporal aspects (Dzieżyc, 1989; Kowalik, 1989; Koźmiński and Michalska, 2001; Kuźniar, 2001; Łabędzki, 1996). They present, however, spatial and temporal distribution of water deficits out of the context of real soil cover in the region. Initially, the deficits were calculated based on climatic indices and then parameterized to plan the location and installation of sprinklers. One of the first Polish researchers that paid attention to the contribution of soil retention in covering water demands of crop

*Corresponding author e-mail: 1.labedzki@itp.edu.pl plants was Kryszan (1986), who considered the so-called effective useful retention when estimating water deficits and assumed three indicator values of soil retention (EUR $=50,70$, and $100 \mathrm{~mm}$ ). For many years, actually until now, the method by Roguski et al. (1988) has been used to determine water deficits, where the amount of water easily available for particular soil types is taken from Ślusarczyk (1979) or estimated based on the retention curve. Soil water retention understood in this way has an effect on estimates of water deficits and on the effectiveness of predicting water reserves necessary for irrigation.

Various deterministic modelling tools have been developed to calculate soil moisture content and crop water deficits, mainly to determine irrigation requirements and to assist in irrigation planning and water management. To make reliable estimation of water deficits of cropped plants, it is indispensable to take into consideration soil water that can be useful for plants. Soil water balance is a commonly accepted and widely used method. The FAO approach based on a simple soil water balance model CROPWAT accounts for soil moisture content and meteorological parameters (Smith, 1992a; Teixeira and Pereira, 1992; Pereira et al., 1995, 2003). The mostly used standard modelling approach is based on the FAO guidelines to estimate crop water requirement (Allen et al., 1998). Precipitation, evapotranspiration, water inflow and run-off to and from the root zone, and changes in soil water retention are the main components of the water balance equation taken into account. The detailed procedures and recommendations how they can and should be calculated are presented and discussed by Doorenbos and Pruitt (1977), Roguski et al. (1988), and Allen et al. (1998).

(C) 2015 Institute of Agrophysics, Polish Academy of Sciences 
We highlight only a few issues relevant for the presented study. Cramer and Prentice (1988) developed a simple deterministic simulation model for landscape-scale soil water deficits. Standard weather station data were used to estimate precipitation and actual (regional) evapotranspiration. The simple soil water balance was used. The model estimates geographical patterns of soil water deficit at a scale suitable for comparison with the distributions of plant species and soil types. Knox et al. (1996) developed a procedure for mapping the spatial distribution of water demands for potatoes in England and Wales using a geographic information system (GIS). The maps take into account crop, climate, and soil factors. Thomas (2000) states that soil water content is mainly dependent on precipitation, evapotranspiration, and soil characteristics. It directly determines the amount of water available to field crops and in turn yields and irrigation requirements. Using the soil water balance, he estimated water deficits and their multi-year trends for field crops in China. Also for China, Tao et al. (2003) analysed agricultural water demands and deficits using a crop-soil-water balance model developed by Smith (1992a,b). Tao et al. (2009) optimized and tested a crop-weather model for spring maize on the Northeast China Plain and summer maize on the North China Plain using soil water balance taking into account snowmelt, percolation, rainfall, evapotranspiration, and runoff. Analyzing different methods for monitoring soil water status, Jones (2007) states that the indirect estimation of water status on the basis of soil moisture balance calculation is widely adopted, especially for agronomic and irrigation purposes. Hedley and Yule (2009) show the application of soil water capacity maps created using a soil water balance prediction model to optimize the use of irrigation water. Wriedt et al. (2009) applied the crop growth model EPIC to calculate irrigation water requirements in the EU and Switzerland, combining available regional statistics on crop distribution and crop specific irrigated area with spatial data sources on soils, land use, and climate.

The aim of this paper is to show possibilities of the use of modelling water deficits with agro-meteorological parameters and spatial analysis to characterise water deficits of selected crop plants with respect to soils on which they can be grown on example of Poland.

\section{MATERIALS AND METHODS}

The demand for water in plant field production cannot be estimated with a single index. For an appropriate course of physiological processes during the vegetation season, grown plants require different water supplies. This is an outcome of genetic features, specific growth of particular plants and of resultant yielding. Having in mind these determinants, a concept has emerged of a complex approach to the problem with the use of modelling, spatial analysis, and cartographic presentation of results obtained. To solve the problem, apart from selecting analysed plants, the following data had to be acquired and collected:

- long-term data on spatial differentiation of agrometeorological conditions that determine water deficits of the selected plants all over the country,

- plant coefficients for the selected plants to calculate water demands with the Penman-Monteith method,

- information on spatial distribution of soils the plants are grown on,

- hydrological and physical soil characteristics.

Water deficits in soils for the selected plants were calculated for 40 meteorological stations of the Institute of Meteorology and Water Management and the Institute of Technology and Life Sciences (previously the Institute for Land Reclamation and Grassland Farming, IMUZ) for the years 1970-2004 using a database of long-term ten-day period values of temperature, air humidity, insolation (sunshine hours), wind speed, and precipitation.

Soils appropriate for the selected plants were singled out based on the relations between the complexes of soil agricultural usefulness and types, sub-types, and kinds of arable soils and on the usefulness of the soils within these complexes for growing plants which were estimated and published by the Institute of Soil Science and Plant Cultivation (Witek, 1973).

Index values of potential useful retention in a $100 \mathrm{~cm}$ soil layer were calculated with respect to generalized soil units contained in the soil-cartographic database of IMUZ based on hydrological and physical characteristics of these units elaborated by the Institute of Agrophysics of the Polish Academy of Sciences, Lublin, Poland and IMUZ (Walczak et al., 2002).

Spatial distribution of arable soils - a base for cartographic imaging of water deficits - was taken from the soil-cartographic database (Ostrowski, 1996) containing digital records of a generalized map of arable soils in Poland in the scale 1:1000 000 .

Crop water deficits were calculated with the model CROPDEF (Łabędzki, 1996, 2006). The model is based on the water balance of the soil root zone and the methods proposed by Allen et al. (1998), Doorenbos and Pruitt (1977), and Roguski et al. (1988). Making the balance of each year starts with the assumption of full soil useful retention in spring (at field water capacity). Calculations are performed for ten-day periods, months, and the whole vegetation period (April - September) as a sum of ten-day values. Reserves of useful water in the soil root zone (temporally variable but constant in the ten-day period) of a given plant is calculated for the vegetation season starting from April 1, according to the equation:

$$
Z W U_{p t}=Z W U_{k(t-1)}=Z W U_{p(t-1)}+P_{t-1}+W G_{t-1}-E T p_{t-1}
$$


where: $Z W U_{p t}$ - reserve of useful water in the root zone at the beginning of the ten-day period $t(\mathrm{~mm}) ; Z W U_{k(t-1)}$, $\mathrm{Z} W U_{p(t-1)}$ - reserve of useful water in the root zone at the end and at the beginning of the period $t-1$, respectively $(\mathrm{mm}) ; P_{t-1}-$ precipitation in the period $t-1(\mathrm{~mm})$; $E T p_{t-1}$ - potential evapotranspiration in the period $t-1(\mathrm{~mm})$, $W G_{t-1}$ - water inflow through capillary rising from deeper soil layers to the root zone in the period $t-1(\mathrm{~mm})$.

Potential evapotranspiration ETp in a ten-day period $(\mathrm{mm})$ ie the actual evapotranspiration of plants at sufficient soil moisture is calculated as:

$$
E T p=k_{c} E T_{\text {o }}
$$

where: $E T_{0}$ - reference evapotranspiration according to Penman-Monteith $(\mathrm{mm}), k_{\mathrm{c}}$ - plant coefficient dependent on the growth phase of a plant and on the yield.

The depletion of easily available water, at which plant growth is not limited, was adopted as a criterion of water deficit in the ten-day period $t-1$ of the vegetation season. For a period when easily available water is depleted, water deficit $N_{t-1}(\mathrm{~mm})$ in the ten-day period $t-1$ is calculated from the equation:

$$
N_{t-1}=Z W T D-Z W U_{k(t-1)}
$$

where: $Z W T D$ - reserve of hardly available water $(\mathrm{mm})$.

The reserve of hardly available water is calculated using the coefficient of water availability $p$ :

$$
Z W T D=(1-p) Z W U
$$

where: $Z W U$ - reserve of useful water $(\mathrm{mm})$ calculated as:

$$
Z W U=Z W_{P P W}-Z W_{W T W}
$$

where: $Z W_{P P W}-$ water reserve at the field water capacity $(\mathrm{pF}=2.2)(\mathrm{mm}), Z W_{W T W}-$ water reserve at the moisture state of permanent wilting $(\mathrm{pF}=4.2)(\mathrm{mm})$.

The reserves of useful water in soil were estimated based on the paper by Walczak et al. (2002).

The coefficient of water availability $p$ determines what part of useful water reserves $Z W U$ is easily available to plants. It depends on the growth phase of the plant and the depth of root penetration. In the model, coefficients $p$ for the selected plants were taken from Doorenbos and Pruitt (1977) and Łabędzki (2006).

Plant coefficient $k_{\mathrm{c}}$ depends on the growth phase of the plant and on the yield. Values of this coefficient were estimated for selected crop plants in lysimetric studies (Łabędzki, 2006) and/or based on literature data (Allen et al., 1998; Roguski et al., 1988).

Calculations of changes in the reserves of useful water according to Eq. (1) are performed for a temporally variable depth of the root zone. At present, there are no detailed data on the growth of the root system in various field crops. Therefore, a mean increment of the root zone depth equal $10 \mathrm{~mm} \mathrm{~d}^{-1}$ up to the maximum depth in complete plant development was adopted in the model. For deep-rooted plants $(>100 \mathrm{~cm})$, calculations are performed to the depth of the active layer no deeper than $100 \mathrm{~cm}$.

For these reasons, water deficits calculated with Eq. (3) should be dealt with as reference deficits pertaining to a soil profile not deeper than $100 \mathrm{~cm}$ and to crop plants of high yield feasible at intensive fertilisation and unlimited access to other yield-forming factors. When plants may use water accumulated in soil layers deeper than $100 \mathrm{~cm}$, the deficits might be smaller. This is also true for the period, when the root zone is shallower than $100 \mathrm{~cm}$ but fed with water inputs from deeper soil layers. The deficits will also be smaller for final crops smaller than assumed.

In the applied method and model, the input of capillary water from deeper layers to the present root zone due to the difference in soil water potential is represented by component $W G$ in Eq. (1). Its share in covering the demands of evapotranspiration and in supplementing water reserves in the root zone depends on the difference of water potential in particular soil layers and on conductive soil properties. This component was assessed based on literature data. Renger and Streber (1982) gave the values of: $0.15,0.2 \mathrm{~mm} \mathrm{~d}^{-1}$ for medium sand and loam, respectively and up to $2 \mathrm{~mm} \mathrm{~d}^{-1}$ for silt formations. Doorenbos and Pruitt (1977) suggested that water input to the root zone ranging from $0.1 \mathrm{~mm} \mathrm{~d}^{-1}$ in loamy sand to $1.5 \mathrm{~mm} \mathrm{~d}^{-1}$ in sandy loam could be a good approximation in the applied method.

Water deficits in soils for selected plants are calculated in points determined by the geographic coordinates of a particular meteorological station at estimated probabilities. Water deficits are calculated for a given probability of exceedance with the application of Pearson type III random probability distribution. Calculated probability determines the frequency of occurrence of deficits with a specific or higher value. For example, a probability of $50 \%$ means that a given (or higher) water deficit appears every second year, a probability of $20 \%$ - once in five years.

The calculations performed provided data for a given plant and attributed soil with the consideration of the two above-mentioned probability thresholds referred to the articular meteorological stations. The data served to create a database that enabled preparing spatial illustration of water deficits for each of the calculated variants in a form of maps of deficits.

Radial basis functions with regularized spline were used to transform the point data obtained (from the sites of the meteorological stations) in order to delineate areas of relatively uniform water deficits for a given soil and plant at a probability of 20 and $50 \%$. Isolines marked by border values of ranges outlining relatively uniform zones of deficits were drawn with this method. In total, 300 analytical maps were generated. The water deficit ranges of 40 $\mathrm{mm}$ were established. Such a choice was substantiated by Drupka et al. (1997), who concluded, after discussing the 
size of sprinkling doses, that such a value may be considered a limit of effective single sprinkling that prevents from gravitational water outflow from the soil profile.

Based on minimum and maximum deficits, seven ranges were established with the following values: 0-40, 40-80, $80-120,120-160,160-200,200-240$, and $240-280 \mathrm{~mm}$ at maximum estimated water deficit for sugar beets equal $260.6 \mathrm{~mm}$ and probability of 20 and $50 \%$.

The assumption of the thematic map concept was to create a map of complex thematic content (a component of spatial information) indicating the occurrence of areas predisposed to growing particular plants and to prepare thematic information presenting the division of these areas with respect to soils and water deficits.

According to the conceptual assumptions presented above, the first stage of computer edition of the map consisted in introduction of a digital record of analytical maps of water deficits and creation of two layers (for 20 and 50\% probabilities) overlapping in the raster record 'pixel on pixel' the layer of soil cover in the Soil-Cartographic Database. The next step of processing consisted in selecting soils suitable for particular plants and soil symbols according to deficit ranges the soils were classified to. One should underline a complex character of classification since a given soil suitable for growing some plants is characterized by different deficits depending on its location due to spatial variability of agro-climatic conditions in the country. As a result, layers with a digital record of the selective map of deficits were created in a set plant - soil - deficits. In a subsequent stage of processing, a cartographic model was created which considered the input and visualisation of information on soil cover.

In total, 24 synthetic maps were generated and published in the atlas of water deficits (Ostrowski et al., 2008). Visual inspection shows a practical advantage of maps edited in this way whose colour underlines the main element (water deficits) with additional information given in symbols of soils present there.

\section{RESULTS AND DISCUSSION}

Necessary data to analyse the problem are given in Table 1. The background of the presented set up consists of agricultural soils in Poland generalized to possible cartographic presentation in the scale 1:1000000. Because of their different properties and agricultural usefulness, the table is not filled completely. 'Windows' without deficit records mean that a given soil is not suitable for the considered plant. Also, water deficits for a given plant in different soils are not uniform due to the different retention capacity of soils, regional differentiation of supply by rainfalls, and evapotranspiration intensity. It should be remembered here that the model assumed the input and output of rainfall water in a $100 \mathrm{~cm}$ soil layer without possible supplementation of water reserves from capillary rising or water uptake by plants from deeper soil layers.

With the exception of plants grown on loess soils with the greatest retention capacity and present in places with sufficient precipitation and comparable evaporation, the range of deficits in the particular soil - plant combinations was variable. This was a result of the geographic distribution of soils and variable climatic conditions (precipitation - evapotranspiration) at the same water demands of a given plant.

The widest ranges of water deficits $(40->240 \mathrm{~mm})$ were found in sugar beet crops on light loamy soils, in legume crops grown for fodder, and in pastures $(40-240 \mathrm{~mm})$. The smallest water deficits were noted in winter rape crops irrespective of soils because of their early growth and maturing at the substantial share of past-winter water reserves in soil. The biggest water deficits were characteristic for fodder plants (clover, alfalfa, grasses), which showed relatively higher water consumption in the production of abundant above-ground biomass than eg cereals, which had a shorter vegetation season and used less water for biomass production.

Noteworthy, the calculated deficits are potential and not permanent indices with the probability of occurrence once in 5 years. Real deficits in the next years may be different or even absent depending on the amount and distribution of precipitation and on the intensity of evapotranspiration.

Soils made of light loams (Eutric Cambisols and Haplic Podzols) and Eutric Cambisols made of silts of hydrogenic origin are most universal in view of their suitability for growing the study plants at relatively biggest water deficits. Equally universal light silty loams (Eutric Fluvisols) determine much smaller water deficits of plants grown there.

As already mentioned, water deficits are the outcome of plant demands for water, soil retention capacity, precipitation infiltrating the soil profile, and the intensity of evapotranspiration. Therefore, identical or similar water deficits may occur in different soils and plant crops in different regions. This is illustrated by data given in Table 2 which should be seen selectively since the same soils are suitable for growing different plants.

Closer inspection of the table indicates that the general range of water deficits is differentiated. This is also associated with the length of the plant vegetation period. Therefore, a similar range of water deficits of particular cereal plants practically does not exceed $120 \mathrm{~mm}$ with the probability of occurrence once every 5 years. Winter rape has the most naturally covered water demands (deficits $<40 \mathrm{~mm}$ ) and late potato - the least, which is obvious since the latter grows on light soils with small retention and its growing season lasts from May till October. Apart from rape and potato, one may generally state that water deficit practically does not exist on $30-40 \%$ of areas suitable for growing particular plant species. 
WATER DEFICITS OF CULTIVATED PLANTS

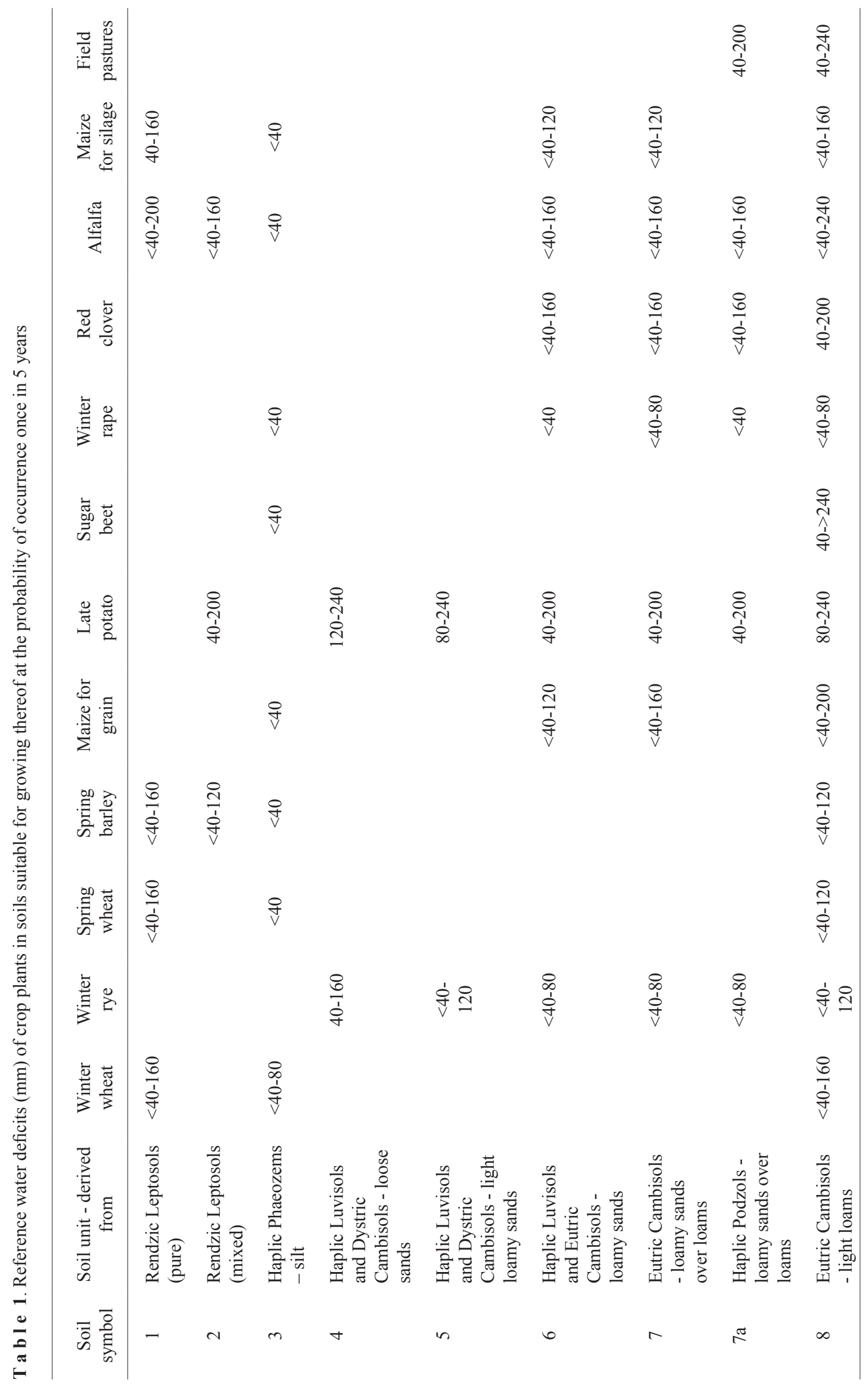




\begin{tabular}{|c|c|c|c|c|c|c|c|c|c|c|}
\hline 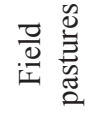 & 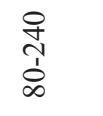 & $\begin{array}{l}\text { \& } \\
\text { ড̀ }\end{array}$ & $\frac{8}{\frac{8}{3}}$ & $\frac{8}{\frac{8}{9}}$ & & & $\begin{array}{l}8 \\
\frac{8}{1} \\
\frac{1}{9}\end{array}$ & 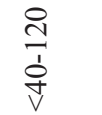 & 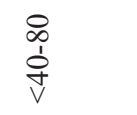 & $\frac{\stackrel{9}{1}}{\frac{\sigma}{\alpha}}$ \\
\hline 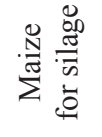 & $\frac{8}{\frac{8}{3}}$ & $\begin{array}{l}8 \\
\frac{8}{1} \\
\frac{1}{9}\end{array}$ & 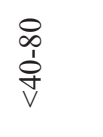 & $\frac{\stackrel{9}{7}}{\frac{\sigma}{\sigma}}$ & 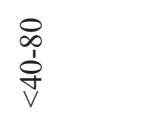 & & 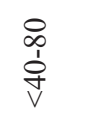 & 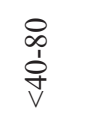 & P & 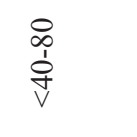 \\
\hline 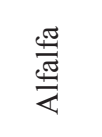 & $\begin{array}{l}\text { 亲 } \\
\text { ơ }\end{array}$ & 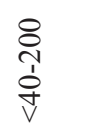 & $\begin{array}{l}\text { ปิ } \\
\frac{3}{3} \\
\text { v }\end{array}$ & 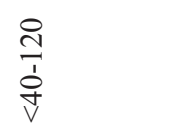 & 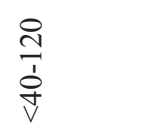 & & $\begin{array}{l}\stackrel{8}{\circ} \\
\frac{1}{+} \\
\stackrel{+}{V}\end{array}$ & 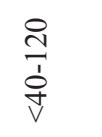 & P & 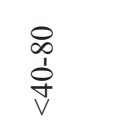 \\
\hline 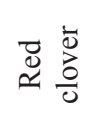 & $\begin{array}{l}8 \\
\text { ণิ } \\
\text { के }\end{array}$ & 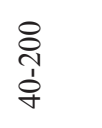 & $\begin{array}{l}\text { ণิ } \\
\text { 守 }\end{array}$ & & & & $\begin{array}{l}\frac{8}{8} \\
\frac{1}{9} \\
\frac{1}{V}\end{array}$ & 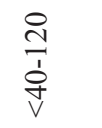 & g & \\
\hline 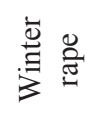 & 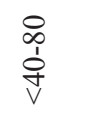 & $\begin{array}{l}\text { o } \\
\text { o. } \\
\text { Oें }\end{array}$ & 암 & & I & & P & o & \& & i \\
\hline 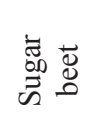 & $\begin{array}{l}\stackrel{ }{+} \\
\hat{\lambda} \\
\grave{D}\end{array}$ & 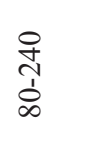 & $\frac{8}{9}$ & & & & $\begin{array}{l}\stackrel{8}{\mathrm{~T}} \\
\text { 广े } \\
\text { 广̀ }\end{array}$ & $\begin{array}{l}\frac{8}{8} \\
\frac{1}{9} \\
\frac{1}{V}\end{array}$ & $\stackrel{P}{\vee}$ & \\
\hline 总 䒿 & 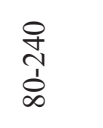 & & & & $\frac{8}{\frac{8}{3}}$ & 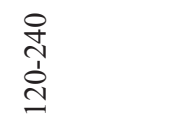 & 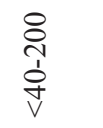 & $\frac{8}{\frac{1}{9}}$ & & \\
\hline 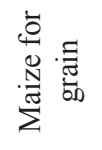 & $\begin{array}{l}\stackrel{8}{1} \\
\text { ஸे } \\
\text { ㄴ }\end{array}$ & 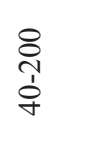 & 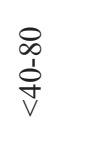 & & 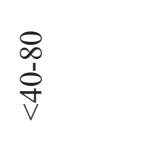 & & 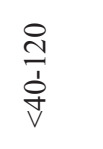 & & o & $\begin{array}{l}\text { o } \\
\text { ì } \\
\text { I্ }\end{array}$ \\
\hline 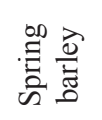 & $\frac{8}{\frac{8}{9}}$ & 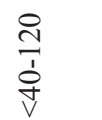 & $\begin{array}{l}\infty \\
\stackrel{\phi}{1} \\
\stackrel{9}{+}\end{array}$ & $\begin{array}{l}\infty \\
\stackrel{1}{1} \\
\dot{P} \\
\forall\end{array}$ & 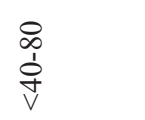 & & $\begin{array}{l}\infty \\
\stackrel{\phi}{1} \\
\stackrel{9}{+}\end{array}$ & & g & \\
\hline 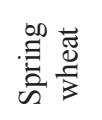 & $\frac{8}{\frac{8}{9}}$ & 突 & 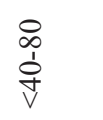 & 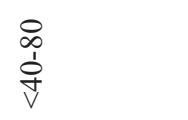 & 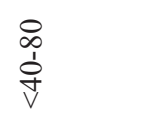 & & 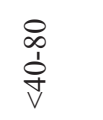 & & o & \\
\hline 曾吕 & 守 I & & & & 守 & $\begin{array}{l}8 \\
\frac{8}{1} \\
\frac{1}{0}\end{array}$ & & P & & \\
\hline 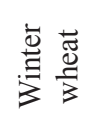 & $\begin{array}{l}\frac{8}{6} \\
\frac{1}{9}\end{array}$ & $\begin{array}{l}8 \\
\frac{8}{1} \\
\frac{1}{1}\end{array}$ & 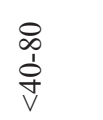 & $\frac{\stackrel{\mathrm{T}}{1}}{\stackrel{+}{+}}$ & & & 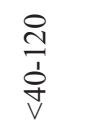 & 高 & 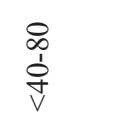 & $\begin{array}{l}\stackrel{0}{0} \\
\dot{1} \\
\dot{q}\end{array}$ \\
\hline 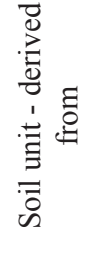 & 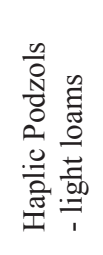 & 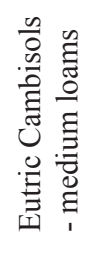 & 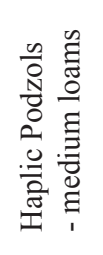 & 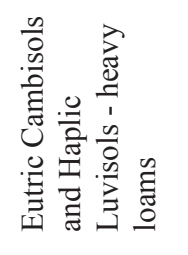 & 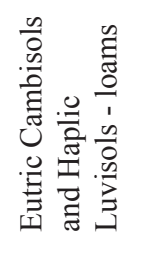 & 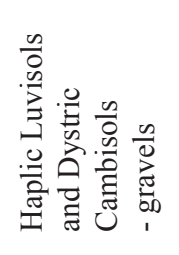 & 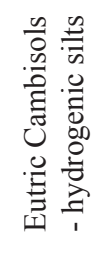 & 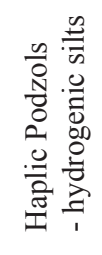 & 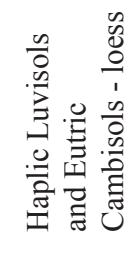 & 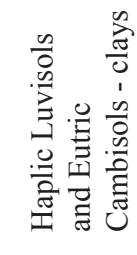 \\
\hline 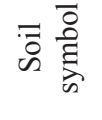 & $\ddot{\infty}$ & $a$ & مూ & 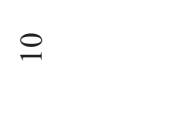 & $=$ & $\simeq$ & 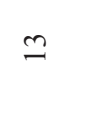 & 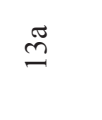 & \pm & $\stackrel{n}{n}$ \\
\hline
\end{tabular}


WATER DEFICITS OF CULTIVATED PLANTS

\begin{tabular}{|c|c|c|c|c|c|c|c|c|c|c|}
\hline 莺 & $\frac{\stackrel{\text { Iิ }}{\grave{+}}}{\stackrel{+}{V}}$ & $\begin{array}{l}\stackrel{\circ}{7} \\
\stackrel{+}{+} \\
\text { V }\end{array}$ & $\begin{array}{l}\stackrel{0}{0} \\
\dot{1} \\
\dot{9} \\
V\end{array}$ & 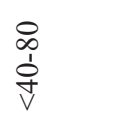 & 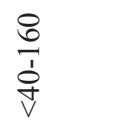 & & 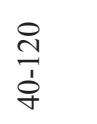 & $\begin{array}{l}\text { \&े } \\
\text { ஸे } \\
\text { ơ }\end{array}$ & $\begin{array}{l}8 \\
\stackrel{\lambda}{1} \\
\grave{1} \\
\infty\end{array}$ & 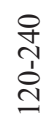 \\
\hline 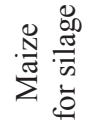 & & & & $\begin{array}{l}\stackrel{0}{\infty} \\
\dot{1} \\
\dot{1} \\
\dot{V}\end{array}$ & $\begin{array}{l}8 \\
\infty \\
1 \\
\dot{1} \\
\forall\end{array}$ & & 암 & $\begin{array}{l}\text { ते } \\
\text { ò } \\
\text { v }\end{array}$ & $\begin{array}{l}8 \\
\frac{1}{1} \\
\dot{1}\end{array}$ & \\
\hline 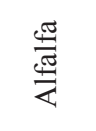 & & $\begin{array}{l}\stackrel{\text { I }}{1} \\
\text { 守 } \\
\text { V }\end{array}$ & $\begin{array}{l}\text { o } \\
\dot{0} \\
\dot{1} \\
\dot{v}\end{array}$ & 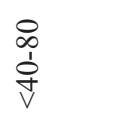 & $\begin{array}{l}\stackrel{0}{0} \\
\stackrel{+}{+} \\
\text { v }\end{array}$ & $\begin{array}{l}8 \\
\stackrel{8}{+} \\
\frac{1}{+} \\
v\end{array}$ & 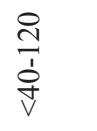 & 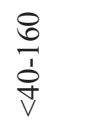 & $\begin{array}{l}8 \\
\frac{1}{1} \\
\dot{0}\end{array}$ & \\
\hline $\begin{array}{l}\overrightarrow{0} \\
\check{0} \\
\stackrel{\overrightarrow{0}}{0}\end{array}$ & & 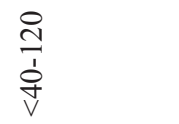 & $\begin{array}{l}8 \\
\infty \\
\dot{1} \\
\dot{P}\end{array}$ & $\begin{array}{l}\stackrel{0}{0} \\
\dot{1} \\
\dot{+} \\
\forall\end{array}$ & $\frac{\stackrel{Ð}{~}}{\stackrel{+}{+}}$ & & $\frac{\stackrel{\overbrace{}}{1}}{\stackrel{+}{+}}$ & $\frac{8}{8}$ & & \\
\hline 离 & & & & & 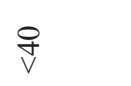 & & 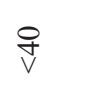 & $\stackrel{P}{\vee}$ & & \\
\hline 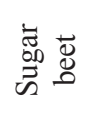 & & & & & & & $\frac{8}{8}$ & 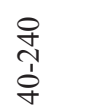 & & \\
\hline 苛 䒿 & $\begin{array}{l}8 \\
\frac{8}{1} \\
\frac{1}{+}\end{array}$ & & & & & $\begin{array}{l}\stackrel{\leftrightarrow}{1} \\
\text { லे }\end{array}$ & $\frac{8}{0}$ & & 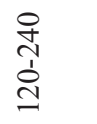 & 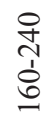 \\
\hline 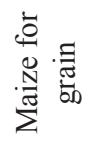 & & & & & $\begin{array}{l}\infty \\
\infty \\
\dot{1} \\
\dot{v}\end{array}$ & & 암 & $\frac{\stackrel{̊}{1}}{\grave{1}}$ & & \\
\hline 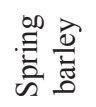 & & & & & $\begin{array}{l}8 \\
\infty \\
\dot{1} \\
\dot{+} \\
\forall\end{array}$ & & $\stackrel{\stackrel{P}{V}}{\mathrm{r}}$ & $\begin{array}{l}0 \\
\infty \\
\dot{1} \\
\dot{P} \\
V\end{array}$ & & \\
\hline 占芯 & & $\begin{array}{l}\text { O } \\
\vdots \\
\dot{1} \\
\dot{P}\end{array}$ & & 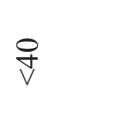 & 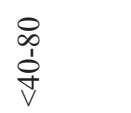 & & $\stackrel{\stackrel{P}{V}}{ }$ & $\frac{\stackrel{\overbrace{}}{1}}{\grave{1}}$ & & \\
\hline 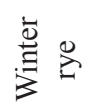 & $\begin{array}{l}\text { o } \\
1 \\
\dot{+} \\
\forall\end{array}$ & $\stackrel{P}{V}$ & $\stackrel{\text { P }}{V}$ & $\stackrel{P}{\vee}$ & & 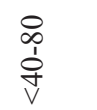 & $\stackrel{\text { P }}{\mathrm{V}}$ & & $\frac{\text { ণิ }}{\stackrel{1}{+}}$ & 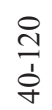 \\
\hline 离 & & & & & $\begin{array}{l}8 \\
\infty \\
\dot{1} \\
\dot{1} \\
V\end{array}$ & & $\begin{array}{l}\stackrel{0}{ } \\
\dot{1} \\
\dot{1} \\
\dot{V}\end{array}$ & 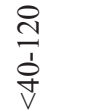 & & \\
\hline 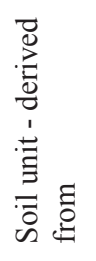 & 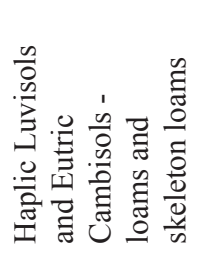 & 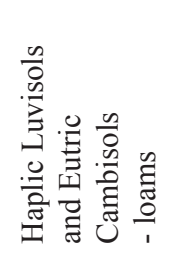 & 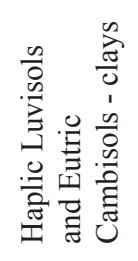 & 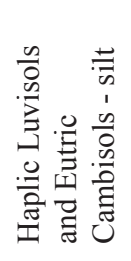 & 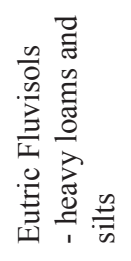 & 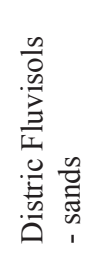 & 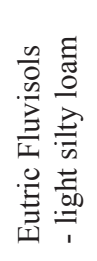 & 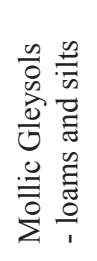 & 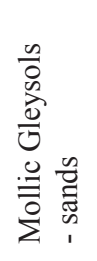 & $\begin{array}{l}0 \\
0 \\
0 \\
0 \\
0 \\
0 \\
0 \\
0 \\
0 \\
0 \\
0 \\
0 \\
0\end{array}$ \\
\hline 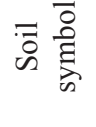 & $\stackrel{\bullet}{0}$ & 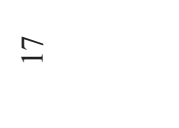 & $\stackrel{\infty}{\infty}$ & 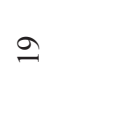 & ¿ & $\vec{\sim}$ & $\tilde{N}$ & $\ddot{\lambda}$ & $\stackrel{\sim}{\sim}$ & $\ddot{\imath}$ \\
\hline
\end{tabular}


T a b l e 2. Area structure of water deficits of crop plants in soils suitable for growing thereof at the probability of occurrence once in 5 years

\begin{tabular}{|c|c|c|c|c|c|c|c|}
\hline \multirow{2}{*}{ Crop } & \multicolumn{7}{|c|}{ Percent of estimated area of soils suitable for growing particular plants in the range of water deficits (mm) } \\
\hline & $<40$ & $40-80$ & $80-120$ & $120-160$ & $160-200$ & $200-240$ & $>240$ \\
\hline Winter wheat & 33.1 & 21.4 & 36.7 & 8.7 & & & \\
\hline Winter rye & 41.1 & 49.3 & 8.8 & 0.8 & & & \\
\hline Spring wheat & 42.2 & 26.5 & 30.3 & 0.9 & & & \\
\hline Spring barley & 37.7 & 30.1 & 31.2 & 0.9 & & & \\
\hline $\begin{array}{l}\text { Maize for } \\
\text { grain }\end{array}$ & 26.7 & 26.3 & 26.5 & 18.6 & 1.8 & & \\
\hline Late potato & 0.3 & 4.2 & 15.6 & 34.8 & 35.8 & 9.3 & \\
\hline Sugar beet & 24.4 & 3.5 & 17.6 & 15.7 & 17.4 & 19.2 & 2.2 \\
\hline Winter rape & 83.0 & 17.0 & & & & & \\
\hline Red clover & 18.1 & 18.3 & 34.3 & 23.6 & 5.7 & & \\
\hline Alfalfa & 26.9 & 5.8 & 22.1 & 25.7 & 17.9 & 1.7 & \\
\hline $\begin{array}{l}\text { Maize for } \\
\text { silage }\end{array}$ & 32.6 & 30.4 & 25.4 & 11.7 & & & \\
\hline Field pastures & 18.2 & 13.6 & 26.7 & 23.8 & 16.3 & 1.4 & \\
\hline
\end{tabular}

T a b l e 3. Correlation coefficient between yield reduction and water deficit in four provinces of Poland in 1999-2010

\begin{tabular}{|c|c|c|c|c|c|}
\hline \multirow[b]{2}{*}{ Crop } & \multirow{2}{*}{$\begin{array}{l}\text { Provinces } \\
\text { together }\end{array}$} & \multicolumn{4}{|c|}{ Province } \\
\hline & & łódzkie & podlaskie & wielkopolskie & $\begin{array}{l}\text { kujawsko- } \\
\text { pomorskie }\end{array}$ \\
\hline Winter wheat & 0.670 & 0.741 & 0.816 & 0.639 & 0.781 \\
\hline Late potato & 0.661 & 0.731 & 0.648 & 0.760 & 0.768 \\
\hline Sugar beet & 0.358 & 0.331 & 0.440 & 0.257 & 0.253 \\
\hline Winter rape & 0.210 & 0.145 & 0.177 & 0.174 & 0.399 \\
\hline Maize for grain & 0.810 & 0.900 & 0.486 & 0.846 & 0.563 \\
\hline Permanent meadows & 0.632 & 0.679 & 0.798 & 0.595 & 0.758 \\
\hline
\end{tabular}

The widest range of water deficits, apart from sugar beets and potatoes, was typical of fodder plants including alfalfa and pasture sward. This may be associated with the ability for biomass regrowth, which practically lasts from April till the end of October.

In the range of water deficits between 40 and $80 \mathrm{~mm}$, the largest areas are occupied by soils suitable for growing rye $(49 \%)$ and maize grown for silage $(30 \%)$; in the range $80-120 \mathrm{~mm}$ - those for spring cereals (30-31\%), winter wheat (37\%), pastures (27\%), and red clover (34\%); in the range $120-160 \mathrm{~mm}$ - those for late potatoes $(35 \%)$ and in the range $160-200 \mathrm{~mm}$ - also those for late potatoes $(36 \%)$. Sugar beets occupy an equal percent of soils (17-19\%) in the ranges of water deficits from 80 to $240 \mathrm{~mm}$.

An important question to answer in the next stage of the study was whether crop water deficits coincide with crop yield reduction. Crop yield reduction is the final negative effect of water deficit. Yield reduction was correlated to water deficit for six crops in the four provinces in 19992010 (Table 3). Water deficit in each year is calculated as 


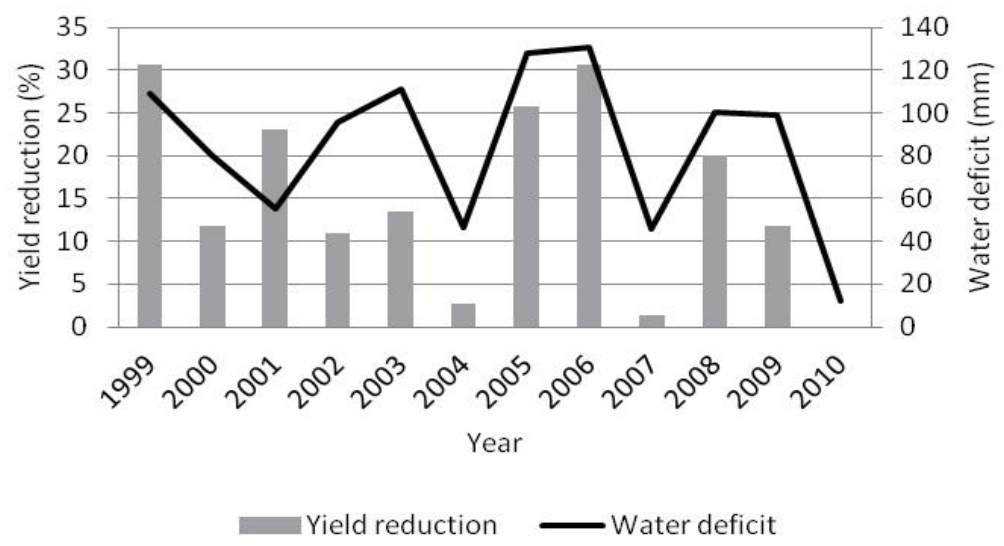

Fig. 1. Water deficit in the growing season and yield reduction of late potato in the kujawsko-pomorskie province in 1999-2010.

the mean value on four soils suitable for growing a given crop, having the largest area in the province. Yields were taken from the official statistic data published by the Central Statisitcal Office. Yield reduction was calculated as the ratio of the yield in each year to the maximum yield obtained in 1999-2010. The results show a good agreement between water deficit and yield reduction (Table 3, Fig. 1). Correlation coefficients are high (0.7-0.9) for crops known as vulnerable to soil drought and mostly affected by water deficit. For more drought resistant crops (winter rape, sugar beet), the correlation is weak. Water deficit caused mostly by precipitation deficit does not affect crops having a short growing period, small water needs, and a deeper root zone than those taken into account in this study $(1 \mathrm{~m})$. Deep rooting enables crops to take water from deeper layers of the soil profile (Aroca et al., 2012).

Comparing the obtained results with other elaborations and publications in a similar subject, it is worth noticing the complex character of the used methods and the results since a given soil suitable for growing some plants is characterized by different deficits depending on its location due to spatial variability of agro-climatic conditions in the country. Previous analyses carried out for the Polish territory show crop water deficits taking into account either only climatic conditions (precipitation, evapotranspiration) or additionally soil water reserves. However, in the latter case, water deficits are shown for a given soil not taking into account the actual occurrence of this soil in the area of Poland. Koźmiński and Michalska (2001) determined the potential reduction in crop yield due to precipitation deficit. Bac and Rojek (1982) elaborated maps of water deficits using climatic water balance without soil water retention and proved that water deficits of $20-30 \mathrm{~mm}$ occur in the area of about 2/3 of Poland. Kryszan (1986), Grabarczyk (1987), Dzieżyc (1987), and Labędzki (1996) took into account soil water retention but they showed spatial distribution of deficits irrespective of the actual location of soils suitable for growing a given plant. In this regard, the deve- loped maps are different from traditional maps where water deficits for crop plants are usually presented separately for every plant and soil on which it grows and the probability of occurrence of these deficits. With the use of the available computer technique, the standard way of cartographic presentation was modified by creating a new concept of a map that shows deficits present in all soils recommended for growing a given plant. Thus, many analytical maps have been replaced by one synthetic map.

Similar mapping of water productivity (defined as yield per unit of water used) for wheat production has been demonstrated for the UK by Zwart et al. (2010). Dodd et al. (2011) estimated that $30 \%$ of the UK wheat acreage is planted on drought-prone land such that $10 \%$ of potential production is lost annually because the moisture available to the crop is insufficient. Those studies and these presented in this article concern crop water deficits as mean values over years or values at a given probability level. It is also necessary to mention the mapping of crop water deficits and forecasted yield losses, made operationally every month for Europe (the EU countries) by the Joint Research Centre, Ispra (Italy), within the MARS project (Monitoring Agriculture with Remote Sensing) (Nieuwenhuis et al., 2015). This system is based on a simple soil water balance model, which is used to assess the impact of weather conditions on crop growth.

Crop water deficit can be used as a measure of net irrigation requirements. Wriedt et al. (2009) created the maps of Europe showing this parameter in each country of EU and Switzerland. The 8-year (1995-2002) simulation period showed that in Central Europe, including Poland, the average net irrigation requirements range from 101 up to $250 \mathrm{~mm}$ per year. They can exceed $250 \mathrm{~mm}$ per year in some locations in the west-central part of the country. These values are similar to those obtained in the presented study. 


\section{CONCLUSIONS}

1. Water deficits for a given plant in different soils are not uniform due to the different retention capacity of soils, regional differentiation of supply by rainfalls, and evapotranspiration intensity. Identical or similar water deficits occurred in different soils and plant crops in different regions. This was a result of geographic distribution of soils and variable climatic conditions (precipitation - evapotranspiration) at the same water demands of a given plant.

2. Water deficits at the probability of $20 \%$ changed in the area of Poland from less than $40 \mathrm{~mm}$ for winter rape to $240 \mathrm{~mm}$ for sugar beet. Water deficit practically does not exist in $30-40 \%$ of soils suitable for growing particular plant species. In the former case, the largest areas are occupied by soils suitable for growing rape $(83 \%)$ and in the latter - for sugar beet $(19 \%)$.

3. Aware that crop yield depends on many factors, a good correlation between water deficit and yield reduction was found. Greater yield reduction occurred in the years with high water deficit for drought-prone plants.

4. Feasibly collected spatial data (parameters necessary for modelling) facilitate cartographic presentation of the occurrence of water deficits for particular crop plants in the scale 1:2500 000. This gives an opportunity of a synthetic view of their regional differentiation.

5. The studies performed allowed spatial and quantitative parameterization of potential reference water deficits for crop plants grown in Poland. Based on these results, one may suggest that the occurrence of water deficits once every 5 years does not pose a serious threat to the development of food production.

6. The main advantage of modelling crop water deficits with mapping tools is that spatial variation in soil, climate, and land use can be accounted for, and so help provide more accurate irrigation demand assessments. This approach would also allow changes in land use and irrigation practice to be modelled to predict future irrigation water requirements.

\section{REFERENCES}

Allen R.G., Pereira L.S., Raes D., and Smith M., 1998. Crop evapotranspiration. Guidelines for computing crop water requirements. FAO Irrigation and Drainage Paper No. 56, Rome, Italy.

Aroca R. (Ed.), 2012. Plant responses to drought stress. Springer, Berlin-Heidelberg, Germany.

Bac S. and Rojek M., 1982. Climatic bases of water balances in Poland (in Polish). In: Agroclimatic Base of Land Reclamation in Poland (Ed. S. Bac). PWRiL, Warsaw, Poland.

Cramer W. and Prentice I.C., 1988. Simulation of regional soil moisture deficits on a European scale. Norwegian J. Geography, 42(2-3), 149-151.

Dodd I.C., Whalley W.R., Ober E.S., and Parry M.A.J., 2011. Genetic and management approaches to boost UK wheat yields by ameliorating water deficits. J. Exp. Botany, 62(15), 5241-5248.
Doorenbos J. and Pruitt W.O., 1977. Guidelines for predicting crop water requirements. FAO Irrigation Drainage Paper No. 52, Rome, Italy.

Drupka S., Kryńska D., and Kuźniar A., 1997. Climatic and agricultural determinants of irrigation requirements in Poland (in Polish). Proc. Seminar, November 19-21, IMUZ Press, Falenty, Poland.

Dzieżyc J. (Ed.), 1989. Water requirements of cultivated crops (in Polish). PWN, Warsaw, Poland.

Grabarczyk S., 1987. Effects, requirements and possibilities of sprinkler irrigation w different regions of the country (in Polish). Zesz. Probl. Post. Nauk Roln., 314, 49-64.

Hedley C.B. and Yule I.J., 2009. Soil water status mapping and two variable-rate irrigation scenarios. Precision Agric., 10, 342-355.

Jones H. G., 2007. Monitoring plant and soil water status: established and novel methods revisited and their relevance to studies of drought tolerance. J. Exp. Botany, 58(2), 119-130.

Knox J.W., Weatherhead E.K., and Bradley R.I., 1996. Mapping the spatial distribution of volumetric irrigation water requirements for maincrop potatoes in England and Wales. Agric. Water Manag., 31, 1-15.

Kowalik P., 1989. Relation between crop water supply and yield (in Polish). In: Water requirements of cultivated crops (Ed. J. Dzieżyc). PWN, Warsaw, Poland.

Koźmiński C. and Michalska B., 2001. Atlas of climatic risk to crop cultivation in Poland (in Polish). Agricultural University, Szczecin, Poland.

Kryszan C., 1986. Spatial distribution of water deficits in Poland (in Polish). Zesz. Probl. Post. Nauk Roln., 268, 37-45.

Kuźniar A., 2001. Effect of soil water retention on water deficits of cultivated plants (in Polish). In: Water use in agrocenosis and its impact on soil-water environment. Proc. Sem., Jaworki, April 24-25, IMUZ Press, Falenty, Poland.

Labędzki L., 1996. Water deficits of cultivated plants as an indicator of small water retention needs (in Polish). In: Needs and possibilities of water retention increase in rural areas. Proc. Semin., 37, 34-63, Wydaw. IMUZ, Falenty, Poland.

Labędzki L., 2006. Agricultural droughts - an outline of problems and methods of monitoring and classification (in Polish). Water-Environment-Rural Areas. Treatises and Monographs. IMUZ Press, Falenty, Poland.

Nieuwenhuis G.J.A., de Wit A.J.W., van Kraalingen D.W.G., van Diepen C.A., and Boogaard H.L., 2015. Monitoring crop growth conditions using the global water satisfaction index and remote sensing. http://www.isprs.org/proceedings/XXXVI/part7/PDF/066.pdf.

Ostrowski J., 1996. Base of soil-cartographic data - structure and use (in Polish). In: Systems of geospatial information. Proc. VI Sci. Conf. Tech. PTIP, June 18-20, Warsaw, Poland.

Ostrowski J., Labędzki L., Kowalik W., Kanecka-Geszke E., Kasperska-Wołowicz W., Smarzyńska K., and Tusiński E., 2008. Atlas of Water Deficits of Cultivated Plants and Grasslands in Poland. IMUZ Press, Falenty, Poland.

Pereira L.S., Teodoro P.R., Rodriguez P.N., and Teixeira J.L., 2003. Irrigation scheduling simulation: The model ISAREG. In: Tools for Drought Mitigation in Mediterranean Regions (Eds G. Rossi, A. Cancelliere, L.S. Pereira, T. Oweis, M. Shatanawi, A. Zairi). Kluwer, Dordrecht, The Netherlands, 161-180. 
Pereira L.S., van den Broek B.J., Kabat P., and Allen R.G. (Eds), 1995. Crop-water-simulation models in practice. Wageningen Press, the Netherland.

Renger M. and Streber O., 1982. Beregnungsbedürftigkeit der LandwirtschaftlichenNutzflächeninNiedersachsen. Geologisches Jahrbuch. Reiche F, 13, 3-66.

Roguski W., Sarnacka S., and Drupka S., 1988. Instruction of estimation of water demands and deficits of cultivated crops and grasslands (in Polish). Instructional Materials, IMUZ Press, Falenty, Poland.

Smith M., 1992a. CROPWAT: A computer program for irrigation planning and management. FAO Irrigation and Drainage Paper No. 46, Rome, Italy.

Smith M., 1992b. Report on the expert consultation on revision of FAO methodologies for crop water requirements. Land Water Devel. Div., FAO, Rome, Italy.

Ślusarczyk E., 1979. Determining water retention of mineral soils for planning and designing irrigation (in Polish). CBS PWM 'Bipromel', 10/75. Melior. Roln. Biull. Inf., 3.

Tao F., Yokozawa M., Hayashi Y., and Lin E., 2003. Changes in agricultural water demands and soil moisture in China over the last half-century and their effects on agricultural production. Agric. Forest Meteorol., 118, 251-261.
Tao F., Yokozawa M., and Zhang Z., 2009. Modelling the impacts of weather and climate variability on crop productivity over a large area: A new process-based model development, optimization, and uncertainties analysis. Agric. Forest Meteorol., 149, 831-850.

Teixeira J.L. and Pereira L.S., 1992. ISAREG, an irrigation scheduling simulation model. ICID Bull., 41, 2, 29-48.

Thomas A., 2000. Climatic changes in yield index and soil water deficit trends in China. Agric. Forest Meteorol., 102, 71-81.

Walczak R., Ostrowski J., Witkowska-Walczak B., and Stawiński C., 2002. Hydrophysical characteristics of mineral arable soils in Poland (in Polish). Acta Agrophysica, 79, 1-140.

Witek T., 1973. Soil-agriculture Maps and Directions of Their Use (in Polish). IUNG Press, Puławy, Poland.

Wriedt G., Van der Velde M., Aloe A., and Bouraoui F., 2009. Estimating irrigation water requirements in Europe. J. Hydrol., 373, 527-544.

Zwart S.J., Bastiaanssen W.G.M., de Fraiture C., and Molden D.J., 2010. A global benchmark map of water productivity for rainfed and irrigated wheat. Agric. Water Manag., 97, 1617-1627. 